\title{
Effect of Dietary REE Supplementation on Blood Biochemical Parameters in Layer Chicken
}

\author{
D. Reka*, V. Thavasiappan, P. Selvaraj and A. Arivuchelvan \\ Department of Veterinary Physiology, Veterinary College and Research Institute, \\ Namakkal - 637 002, Tamil Nadu, India \\ *Corresponding author
}

\section{A B S T R A C T}

A biological study was conducted to determine the effects of dietary supplementation of different levels of rare earth elements (lanthanum and cerium) on blood biochemical parameters namely calcium, phosphorus, total protein, albumin and globulin in laying

\section{Keywords}

Layers, REE,

Plasma calcium,

Plasma phosphorus,

Total protein

Article Info

Accepted:

04 December 2017

Available Online:

10 January 2018 hens. A total of 96 White Leghorn laying hens of 52 weeks of age were used in 8-week feeding trial. Birds were randomly allotted to three dietary treatments each with four replicates and 8 hens per replicate. Treatments consist of basal diet supplemented with 0 , $250 \mathrm{mg}$ (lanthanum $100 \mathrm{mg}$ and cerium $150 \mathrm{mg}$ ) and $500 \mathrm{mg} / \mathrm{kg}$ (lanthanum $200 \mathrm{mg}$ and cerium $300 \mathrm{mg}$ ) of rare earth elements. Blood was collected from the birds at monthly intervals and plasma was separated to analyse calcium, phosphorus, total protein and albumin using UV spectrophotometer. The results in this study showed that rare earth elements (lanthanum and cerium) supplemented at $250 \mathrm{mg} / \mathrm{kg}$ to the diets of layers had significantly $(\mathrm{P}<0.05)$ increased plasma calcium and phosphorus levels at first and second month, whereas in $500 \mathrm{mg} / \mathrm{kg}$ experimental group plasma calcium and phosphorus had significantly $(\mathrm{P}<0.05)$ increased in first month but no significant changes was found in second month of the trial. The total protein, albumin and globulin were not significantly affected compared to the control. Hence it was concluded that at low dose of rare earth elements, the birds had significant effect in plasma calcium and plasma phosphorus level compared to higher dose.

\section{Introduction}

Rare earth elements literally refer to three members of group IIIB, namely scandium, yttrium, lanthanum, and the 14 chemical elements found in group IIIA of the periodic table called lanthanoids (cerium, praseodymium, neodymium, promethium, samarium, europium, gadolinium, terbium, dysprosium, holmium, erbium, thulium, ytterbium and lutetium). Lanthanum and
Cerium are REE widely existing in earth (Raja and Sethuraman, 2008). Lanthanum resembles the element calcium in size, bonding, and coordination geometry and donor atom preference and it may act as calcium analog in various biological processes in laying hens. In animal production, excellent results have also been obtained by incorporating REE in animal diets in Chinese literatures (Redling 2006). The proper concentrations of REE in diet can improve animal growth performance without 
affecting quality of products (He et al., 2001). Growth performance enhancing effects due to dietary supplementation of rare earth elements at low concentrations are described for nearly all categories of farming animals, including beef cattle, sheep, pigs, rabbits, ducks, chickens, shrimps and fish (Redling, 2006).

Therefore the aim of this study was to investigate the effects of dietary rare earth element on blood biochemical indices of laying hens.

\section{Materials and Methods}

A total of 96 White Leghorn layers of 52 weeks of age were randomly assigned to three dietary treatments for 8-week feeding trial and the experiment was conducted at the Poultry Farm Complex, Department of Poultry Science, Veterinary College and Research Institute, Namakkal, Tamil Nadu. Laying hens were randomly assigned to three treatments with four replicates per treatment, and there were 8 hens in each replicate. The layers were reared in cages in gable roofed open sided, elevated platform house. All the birds were provided with uniform cage floor, feeder and water space and were reared under standard management conditions throughout the experimental period. The experimental layer diets were formulated according to the breeder's specification (Venkateshwara Hatcheries Private Limited). Basal diet supplemented with 0, 250 (La 100mg, Ce $150 \mathrm{mg}$ ) and $500 \mathrm{mg} / \mathrm{kg}$ (La 200, Ce $300 \mathrm{mg}$ ) of REE. The ingredients and proximate analysis of nutrients done as per AOAC (1995) are presented in Table 1. Blood (2 ml) was collected from wing vein using $24 \mathrm{G}$ needles in sodium fluoride vacutainer tubes from 18 birds (six birds per treatment) at monthly intervals. The collected blood was immediately centrifuged for $10 \mathrm{~min}$ at 2,000 rpm and the separated plasma was stored at $20^{\circ} \mathrm{C}$ for further biochemical analysis. The blood biochemicals were analyzed with UV-
VIS double beam spectrophotometer (SYSTRONICS, Model 2202, India) using commercial kits (Span diagnostics Ltd., India). Calcium (Trinder, 1960) and phosphorus (Gomorii, 1942), total protein (Lowry et al., 1951), albumin (Johnson et al., 1999) and globulin were determined in the plasma samples as per the manufacture's protocol.

\section{Statistical analysis}

The data collected were analysed using SPSS ${ }^{\circledR} 20.0$ software package. Post hoc analysis was done by Duncan's multiple descriptive significant difference. All the statistical procedures were performed based upon Snedecor and Cochran (1994).

\section{Results and Discussion}

The influence of REE at different levels on the blood biochemical constituents of layer chickens were presented in Table 2 and 3.

The plasma calcium and phosphorus levels were significantly $(\mathrm{P}<0.05)$ high in REE supplemented groups (Table 2). The results in this study showed that rare earth elements (lanthanum and cerium) supplemented at $250 \mathrm{mg} / \mathrm{kg}$ to the diets of layers had significantly increased plasma calcium and phosphorus levels at first and second month, whereas in $500 \mathrm{mg} / \mathrm{kg}$ experimental group plasma calcium and phosphorus had significantly increased in first month but no significant changes was found in second month of the trial. The level of calcium and phosphorus recorded in the present study are accordance with that of Zohravi (2006) who reported significant increase in serum calcium by addition of REE (50 to $100 \mathrm{mg} / \mathrm{kg}$ ) in Japanese quail compared to control birds. Bolukbas et al., (2016) also reported that significantly $(\mathrm{p}<0.05)$ increased serum calcium and phosphorus by supplementing cerium oxide $(100 \mathrm{mg} / \mathrm{kg})$ in layer. 
Table.1 Ingredients and nutrient composition of experimental layer diet (DM \%)

* Calculated values

\begin{tabular}{|l|c|}
\hline \multicolumn{1}{|c|}{ Ingredients } & $\mathrm{Kg} / 100 \mathrm{~kg}$ diet \\
\hline Maize & 50.5 \\
\hline DORB & 13.5 \\
\hline SFOC & 6.0 \\
\hline SOYA & 17.5 \\
\hline Calcite/LSP & 5.5 \\
\hline Grit & 5.0 \\
\hline Di calcium phosphate & 1.5 \\
\hline Methionine & 0.164 \\
\hline Lysine & 0.117 \\
\hline NSP Enzyme & 0.05 \\
\hline Salt & 0.137 \\
\hline Nutrient compositions (\%) & \\
\hline Crude protein & 16.67 \\
\hline Crude fibre & 6.4 \\
\hline Calcium & 4.0 \\
\hline Ether extract & 3.0 \\
\hline Available phosphorus* & 0.41 \\
\hline Lysine* & 0.89 \\
\hline Methionine* & 0.45 \\
\hline Metabolizable Energy* (kcal/kg) & 2550 \\
\hline
\end{tabular}

Additives and supplements (per $100 \mathrm{~kg}$ ): Vitamin premix ( ${ }^{1}$ Hyblend) - $10 \mathrm{~g}$, trace mineral $\left({ }^{2} \mathrm{Ultra} \mathrm{TM}\right)-100 \mathrm{~g}$, toxin binder - 25 g, Vitamin B-complex ( ${ }^{3}$ Meriplex) - $10 \mathrm{~g}$, liver stimulant (hepatocare) - $25 \mathrm{~g}$, choline chloride $(60 \%)$ $50 \mathrm{~g}$, oxytetracycline $(10 \%)-50 \mathrm{~g}$

${ }^{1}$ Hyblend - nutritional value per gram- vitamin A - $82500 \mathrm{IU}$, vitamin B2 - $50 \mathrm{mg}$, vitamin D3 - $12000 \mathrm{IU}$, menaphthone sodium bisulphate and vitamin K (stabilized) - $10 \mathrm{mg}$.

${ }^{2}$ Ultra TM - Each $5 \mathrm{~kg}$ contains manganese $-270 \mathrm{~g}$, zinc $-260 \mathrm{~g}$, iron - $100 \mathrm{~g}$, iodine - $10 \mathrm{~g}$, copper - $10 \mathrm{~g}$, cobalt $-5 \mathrm{~g}$ selenium - $1.5 \mathrm{~g}$

${ }^{3}$ Meriplex - each gram contains vitamin $B_{1}-8 \mathrm{mg}$, vitamin $\mathrm{B}_{6}-16 \mathrm{mg}$, vitamin $\mathrm{B}_{12}-80 \mathrm{mcg}$, vitamin $\mathrm{E}_{50}-80 \mathrm{mg}$, niacin $-120 \mathrm{mg}$, folic acid $-8 \mathrm{mg}$, calcium D pantothenate $-80 \mathrm{mg}$, calcium $-86 \mathrm{mg}$.

Table.2 Mean $( \pm$ SE) plasma calcium and phosphorus $(\mathrm{mg} / \mathrm{dl})$ of White Leghorn layers fed different levels of REE

\begin{tabular}{|c|c|c|c|c|c|c|}
\hline & \multicolumn{5}{|c|}{ Calcium (mg/dl) } & \multicolumn{5}{c|}{ Age in weeks } \\
\hline & 52 & 56 & 60 & 52 & 56 & 60 \\
\hline T1 Control & $26.57 \pm 0.48$ & $26.50^{\mathrm{a}} \pm 0.36$ & $26.72^{\mathrm{a}} \pm 0.45$ & $6.98 \pm 0.14$ & $7.01^{\mathrm{a}} \pm 0.13$ & $7.00^{\mathrm{a}} \pm 0.11$ \\
\hline $\begin{array}{c}\text { T2 } 250 \mathrm{mg} \text { REE } \\
\text { (La 100 } \mathrm{mg}+150 \mathrm{mg} \text { Ce) }\end{array}$ & $25.81 \pm 0.78$ & $28.17^{\mathrm{b}} \pm 0.51$ & $28.95^{\mathrm{b}} \pm 0.33$ & $6.97 \pm 0.10$ & $8.03^{\mathrm{b}} \pm 0.15$ & $7.78^{\mathrm{b}} \pm 0.22$ \\
\hline T3 $500 \mathrm{mg} \mathrm{REE}$ & $26.48 \pm 0.52$ & $28.12^{\mathrm{b}} \pm 0.56$ & $27.08^{\mathrm{a}} \pm 0.35$ & $7.02 \pm 0.17$ & $7.67^{\mathrm{b}} \pm 0.18$ & $7.20^{\mathrm{a} \pm 0.6}$ \\
\hline (La $200 \mathrm{mg}+300 \mathrm{mg}$ Ce) & & & & & & \\
\hline
\end{tabular}

Means bearing different superscript within the column differ significantly $(\mathrm{P}<0.05)$ 
Table.3 Mean ( \pm SE) plasma total protein, albumin and globulin $(\mathrm{g} / \mathrm{dl})$ of White Leghorn layers fed different levels of REE

\begin{tabular}{|c|c|c|c|c|c|c|c|c|c|}
\hline \multirow[t]{3}{*}{ TREATMENTS } & \multicolumn{3}{|c|}{ Total protein (g/dl) } & \multicolumn{3}{|c|}{ Albumin (g/dl) } & \multicolumn{3}{|c|}{ Globulin (g/dl) } \\
\hline & \multicolumn{9}{|c|}{ Age in weeks } \\
\hline & 52 & 56 & 60 & 52 & 56 & 60 & 52 & 56 & 60 \\
\hline $\begin{array}{c}\mathrm{T} 1 \\
\text { Control }\end{array}$ & $\begin{array}{l}3.88 \pm \\
0.07\end{array}$ & $\begin{array}{l}3.91 \pm \\
0.12\end{array}$ & $\begin{array}{c}3.88 \pm \\
0.10\end{array}$ & $\begin{array}{c}2.29 \pm \\
0.01\end{array}$ & $\begin{array}{l}2.37 \pm \\
0.05\end{array}$ & $\begin{array}{l}2.38 \pm \\
0.06\end{array}$ & $\begin{array}{l}1.59 \pm \\
0.07\end{array}$ & $\begin{array}{l}1.54 \pm \\
0.09\end{array}$ & $\begin{array}{l}1.50 \pm \\
0.06\end{array}$ \\
\hline $\begin{array}{c}\text { T2 } \\
250 \mathrm{mg} \text { REE } \\
(\mathrm{La} 100 \mathrm{mg} \\
+150 \mathrm{mg} \mathrm{Ce})\end{array}$ & $\begin{array}{l}3.91 \pm \\
0.07\end{array}$ & $\begin{array}{l}3.92 \pm \\
0.07\end{array}$ & $\begin{array}{l}3.90 \pm \\
0.04\end{array}$ & $\begin{array}{l}2.34 \pm \\
0.03\end{array}$ & $\begin{array}{l}2.40 \pm \\
0.06\end{array}$ & $\begin{array}{l}2.31 \pm \\
0.07\end{array}$ & $\begin{array}{l}1.57 \pm \\
0.08\end{array}$ & $\begin{array}{l}1.51 \pm \\
0.02\end{array}$ & $\begin{array}{l}1.58 \pm \\
0.05\end{array}$ \\
\hline $\begin{array}{c}\text { T3 } 500 \text { mg REE } \\
\text { (La } 200 \text { mg } \\
+300 \mathrm{mg} \mathrm{Ce} \text { ) }\end{array}$ & $\begin{array}{c}3.92 \pm \\
0.08\end{array}$ & $\begin{array}{c}3.90 \pm \\
0.10\end{array}$ & $\begin{array}{c}3.85 \pm \\
0.10\end{array}$ & $\begin{array}{c}2.37 \pm \\
0.03\end{array}$ & $\begin{array}{c}2.38 \pm \\
0.06\end{array}$ & $\begin{array}{l}2.32 \pm \\
0.07\end{array}$ & $\begin{array}{l}1.55 \pm \\
0.05\end{array}$ & $\begin{array}{c}1.52 \pm \\
0.12\end{array}$ & $\begin{array}{c}1.52 \pm \\
0.14\end{array}$ \\
\hline
\end{tabular}

Brown et al., (1990) reported that REE were considered to be as analogous to $\mathrm{Ca}$, especially lanthanum ( $\mathrm{La})$ had been named as super calcium. REEs locate at the same binding sites in organisms as $\mathrm{Ca}$ and thus show a similar effect with that of $\mathrm{Ca}$. It is thought that REE may also increase $\mathrm{Ca}$ ratio of serum in this study.

The mean plasma total protein, albumin and globulin concentration did not show any significant variation among the treatment groups (Table 3 ). The results of the present study concurred with He et al., (2001) at $300 \mathrm{mg} / \mathrm{kg}$ in pigs, Adu et al., (2009); Adu et al., (2011b) at 100,200,300,400 ppm in rabbits and Adu et al., (2011a); Igbasan and Adebayo (2012) at 100,200,300 ppm supplementation of REE in broilers.

In conclusion $250 \mathrm{mg} / \mathrm{kg}$ REE had significant effect on plasma calcium and phosphorus levels in laying hens. Growth promoters or performance enhancers are used worldwide in animal production. Rare earth elements (REE) have been shown to influence growth performance in animals. Probiotics, prebiotics, organic acids and enzymes are already known as replacements for antibiotics as feed additives but rare earth elements (REEs) might be the new generation of growth promoters.

\section{References}

A.O.A.C. 1995. Official Methods of Analysis Association of Official Analytical Chemists, 16th Edn., Washington, D.C, USA.

Adu, O.A., Igbasan, F.A. and Adebiyi, O.A. 2011a. Effect of dietary rare earth element on performance and carcass characteristics of broiler. J. Sus. Techn, 2: 118-126.

Adu, O.A., Ladipo, M.K., Adebiyi, O.A., Akinfemi, A. and Igbasan, F.A. 2009. Performance and blood characteristics of pre-pubertal rabbits fed varied levels of dietary rare earth element (REE). World Appl. Sci. J., 6: 1489-1494.

Adu, O.A., Omoleye, O. S., and Asolo, O. H. 2011b. Performance and blood profile of rabbits fed varied dietary lanthanum oxide. Elixir Agri., 35: 2788-2791.

Bölükbaşı, S. C., Al- sagan, A. A., Ürüşan, H., Erhan, M. K., Durmuş, O., and Kurt, N. 2016. Effects of cerium oxide supplementation to laying hen diets on performance, egg quality, some antioxidant enzymes in serum and lipid oxidation in egg yolk. J. anim. Physiol. anim. Nutr, 100: 686-693.

Brown, P.H., Rathjen, A.H., Grahahm, R.D. and Tribe, D.E. 1990. Rare earth elements in biological systems, in: 
Gschneidner Jr. K. A., Eyring, L. Roy (Eds.), Handbook on the physics and chemistry of rare earths. Amsterdam, Oxford: Elsevier North-Holland. pp: 92.

Durmuş, O., and Bölükbaşı, Ş. C. 2015. Biological activities of lanthanum oxide in laying hens. J. Appl. Poult. Res., 24: 481-488.

Gomorii, G., 1942. A modification of the colorimetric phosphorus determination for use with the photoelectric colorimeter. J. Lab. Clin. Med., 27: 955960.

He, M. L., Ranz, D. and Rambeck, W. A. 2001. Study on the performance enhancing effect of rare earth elements in growing and fattening pigs. J. Anim. Physio. Anim. Nutr., 85: 263-270.

Igbasan, F. A. and Adebayo, O. S. 2012. Growth response, carcass quality, some haematological and biochemical parameters of broiler chickens fed on diets supplemented with lanthanum salts. Int. J. Sci. Eng. Res., 3: 1-17.

Johnson, A. M., Rohlfs, E. M. and Silverman, L. M. 1999. Proteins, In Tietz textbook of clinical chemistry, 3rd Edn., C.A. Burtis and E.R., Eds. W.B. Saunders,
Philadephia. pp: 477-540.

Lowry, O. H., Rosebrough, N. J., Farr, A. L. and Randall, R. J. 1951. Protein measurement with the Folin phenol reagent. J. Biol. Chem., 193: 255-265.

Raja, P. B. and Sethuraman, M. G. 2008. Natural products as corrosion inhibitor for metals in corrosive media-a review. Materials Letters, 62: 113-116.

Redling, K. 2006. Rare earth elements in agriculture with emphasis on animal husbandry. Diss. the Ludwig Maximilian University, Munich.

Snedecor, G. M. and Cochran, W. C. 1994. Statistical Methods. 9th edn. Oxford and IBM Publishing company, Mumbai, India.

Trinder, P., 1960. Colorimetric micro determination of calcium in serum. Analyst, 85: 889-894.

Zohravi, M., 2006. The effect of rare earth elements on growth performance, tibia mineralization and blood serum of Japanese quails. Dissertation of veterinary Doctorate of Veterinary Faculty of the Ludwig Maximilian, University of Munich.

\section{How to cite this article:}

Reka, D., V. Thavasiappan, P. Selvaraj and Arivuchelvan, A. 2018. Effect of Dietary REE Supplementation on Blood Biochemical Parameters in Layer Chicken. Int.J.Curr.Microbiol.App.Sci. 7(01): 181-185. doi: https://doi.org/10.20546/ijcmas.2018.701.020 